\section{THE DEVELOPMENT OF PUBLIC HEALTH SPORTS IN COLLEGES AND UNIVERSITIES BASED ON THE ANALYTIC HIERARCHY PROCESS}

\author{
ODESENVOLVIMENTO DEESPORTES DE SAÚDE PÚBLICA EM FACULDADES E UNIVERSIDADES BASEADO \\ NO PROCESSO HIERÁRQUICO ANALITICO \\ INVESTIGACIÓN SOBRE EL DESARROLLO DE DEPORTES UNIVERSITARIOS DE SALUD PÚBLICA BASADA \\ ENEL PROCESO DE JERARQUÍA ANALITTICA
}

\section{Xiong Jiang 1 (D) \\ Sports Sociology \\ Yu Zhang ${ }^{1}$ (D) \\ Sports training}

1. College of Physical Education, Hunan Normal University, Changsha, Hunan, 410012, China.

\section{Correspondence:}

Changsha, Hunan, 410012, China. jupuzhong625@163.com

\begin{abstract}
With the increasing public attention to public health sports in colleges and universities, the development of public health sports urgently needs more scientific methods to be optimized. Based on this, this paper proposes to use AHP to optimize the design of public health sports in colleges and universities. Based on the simple analysis of the development of public health sports in colleges and universities and the application of AHP, this paper takes the healthy development of public health sports in colleges and universities as the guiding ideology, applies the analytic hierarchy process to course selection and student evaluation, gives different weights to the influencing factors of course selection and evaluation, and carries out simulation analysis with an example. The test results show that the application of AHP in public health sports can improve the effect of course selection and realize the diversity of teaching evaluation.
\end{abstract}

Keywords: Public health sports; analytic hierarchy process; course selection; teaching evaluation.

\section{RESUMO}

Com a crescente atenção do público aos esportes de saúde pública em faculdades e universidades, o desenvolvimento de esportes de saúde pública precisa urgentemente de métodos mais científicos para ser otimizado. Com base nisso, este artigo propõe usar o AHP para otimizar a concepção de esportes de saúde pública em faculdades e universidades. Com base na análise simples do desenvolvimento dos desportos de saúde pública em faculdades e universidades e na aplicação do AHP, este documento tem o desenvolvimento saudável dos desportos de saúde pública em colégios e universidades como ideologia orientadora, aplica o processo hierárquico analítico à seleção de cursos e à avaliação dos estudantes, dá pesos diferentes aos fatores que influenciam a seleção e avaliação dos cursos, e realiza a análise de simulação com um exemplo. Os resultados dos testes mostram que a aplicação do AHP nos esportes de saúde pública pode melhorar o efeito da seleção de cursos e realizar a diversidade da avaliação do ensino.

Descritores: Desporto de saúde pública; processo hierárquico analítico; seleção de cursos; avaliação pedagógica.

\section{RESUMEN}

Con la creciente atención a los deportes de salud pública en los colegios y universidades, el desarrollo de los mismos necesita con urgencia la optimización de más métodos científicos. Considerando esto, este trabajo propone utilizar PJA para optimizar el diseño de deportes de salud pública en colegios y universidades. Basado en el análisis simple del desarrollo de deportes de salud pública en colegios y universidades y la aplicación de PJA, este documento toma el desarrollo saludable de deportes de salud pública en colegios y universidades como la ideología rectora, aplica el proceso de jerarquía analítica a la selección de cursos y evaluación de los estudiantes, da diferentes ponderaciones a los factores que influyen en la selección y evaluación de cursos y realiza análisis de simulación con un ejemplo. Los resultados de la prueba muestran que la aplicación de PJA en deportes de salud pública puede mejorar el efecto de la selección de cursos y entender la diversidad de la evaluación de la enseñanza.

Descriptores: Salud pública y Deportes; análisis de niveles; selección de planes de estudio; evaluación de la enseñanza.

\section{INTRODUCTION}

College students are not only the backbone of national development, but also one of the important sources to promote the progress of the society. College students have a strong plasticity, so colleges and universities in the cultivation of students in addition to the professional level of students, moral education and physical education are highly valued In order to realize the "healthy China dream" as soon as possible, the CPC Central Committee formulated "healthy China 2030" in 2016, and made "health education" an important part of the education stage. In this environment, the development of health physical education has been widely concerned by the society. At present, the public health sports in Colleges and universities mostly use the "big class" teaching 
method. As time goes on, in the later stage of teaching, the method of students' course selection is adopted to improve the effectiveness of teaching, and the learning effect of students is evaluated at the end of each term. ${ }^{1}$ With the continuous promotion of teaching and sports reform, more and more educational ideas do not appear, among which the "people-oriented" education concept has been widely valued and gradually implemented. It is also pointed out in the P.E. Teaching Syllabus of colleges and universities that students should have the right to choose PE courses freely and choose the class time freely, but so far, this has not been fully realized. ${ }^{2}$ As an important part of teaching, learning evaluation plays a guiding role and plays a positive role in promoting students' learning and development. Teaching evaluation should be able to fully reflect the development of public health sports, and the contents and methods of comment should be diversified and dynamic in advance. At present, in the evaluation of public health sports in Colleges and universities, most of them evaluate students' skills, overemphasize students' skill indicators, and belong to one-off assessment method, which is not scientific enough. ${ }^{3}$

Based on this, the paper points out that in the development of public health sports in Colleges and universities, the introduction of analytic hierarchy process (AHP) is focused on the application of AHP in students' course selection and evaluation, so as to improve the effectiveness of course selection and the authenticity of evaluation, and promote the development of public health sports in Colleges and universities.

In many studies, it is believed that students have great blindness in selecting courses. Many students are easily affected by their own subjective factors, and also affected by the external environment, and even show difficulty in choosing courses. Therefore, many scholars have introduced a lot of new methods to improve the course selection, so that students can choose their own, meet the needs of sports, but also improve the enthusiasm of students to choose courses. In order to solve this kind of problem, the analytic hierarchy process (AHP) can divide the problems to be solved into different levels, and then divide them into different components according to the requirements, and then cluster analysis is carried out. In the analysis of the teaching effect of flipped classroom, Emir h ü seyin et al. Discussed the problem of course selection for graduate students in the Department of industrial engineering, kirikare University. Through questionnaire survey, all the criteria affecting the effect of course selection are determined, and then the significance level is determined by AHP. According to the pre-determined weights in the AHP results, the PROMETHEE method is used to weight the six grades in the Industrial Engineering Department. ${ }^{4}$

In terms of teaching evaluation in Colleges and universities, most colleges and universities have undergone many changes, but the final examination is still the main method, and the evaluation method is relatively single, so it is difficult to accurately evaluate the learning effect of students. Dorado R and others think that the analytic hierarchy process can be applied in the field of Engineering Teaching. ${ }^{5}$ introduced the analytic hierarchy process (AHP) in the evaluation of College English teaching. By analyzing the selection principle of the evaluation index of English classroom teaching level, the evaluation index system was established. On this basis, the evaluation objects were graded, and the fuzzy membership degree of the evaluation objects under different levels was determined. Then, the corresponding evaluation index weights were obtained by using the analytic hierarchy process (AHP), Based on the fuzzy system theory, a multi index measurement model of College English classroom teaching level is established. The results of case analysis show that the model is feasible. Gueler et al. took the task assignment of teaching assistants in the Department of industrial engineering as the research object, and established a goal programming model.
The punishment for deviation from soft constraints was determined by analytic hierarchy process (AHP). The proposed GP model avoided assigning the same teaching assistant to the same task in consecutive years, that is, sticking a task to the teaching assistant. ${ }^{6}$

To sum up, we can see that there are a lot of research on the application of AHP in teaching, and many scholars have analyzed the specific application methods. However, these studies are relatively one-sided and rarely analyze its application in health sports teaching. Therefore, it is of great practical significance to study the application of AHP in the development of public health sports in Colleges and universities.

\section{Case analysis of course selection}

In the course selection of public health physical education in Colleges and universities, the judgment matrix is constructed after assigning values to each index. The comparison structure is composed of matrix $A$, that is, judgment matrix, where a is reciprocal matrix. According to the judgment matrix, the eigenvector and eigenvalue are calculated, and the eigenvector corresponding to the maximum eigenvalue is normalized. The value obtained is the index weight, which is represented by W. The calculation results are shown in Table 1. In the table, $P$ is expert, $W$ is evaluation index weight, and $\lambda$ is characteristic value. Experts'opinions on various indicators are not fixed. For example, one expert thinks that the nature of the course has a great impact, while others think that the curriculum schedule has the greatest impact. In order to ensure the consistency of the matrix, the closer the eigenvalue is to the number of factors, the more accurate the eigenvector is. The random consistency ratio $\mathrm{Cr}$ is introduced to judge the consistency. The maximum value of $\mathrm{Cr}$ is $9.2 \%$, which indicates that the consistency of judgment matrix is satisfactory.

After the evaluation weight of each expert is calculated, the comprehensive weight can be calculated. At present, geometric average or arithmetic pinjun can be used. The calculation results are shown in Table 1. It can be seen from the data in the table that the difference between the results obtained by the two methods is very small. Among them, the nature of curriculum has the greatest impact, followed by curriculum schedule, random number, campus and course selection time. At the same time, the weighted calculation method is used to check the consistency. The calculation results are shown in Table 2.

Taking the healthy public physical education courses that colleges and universities need to choose in autumn as an example, 100 students can take classes in each course. In the pre selection stage, 300 students are pre selected first. The priority of the students and the level analysis. According to the formula to determine the priority of students, and then sort, get the priority effect. According to the calculation results, the top 100 students are selected from the largest to the smallest, and the remaining students are eliminated and choose other courses. From

Table 1. Vector consistency test

\begin{tabular}{c|c|c|c|c|c|c|c|c|c|c}
\hline & $\boldsymbol{P}_{\mathbf{1}}$ & $\boldsymbol{P}_{\mathbf{2}}$ & $\boldsymbol{P}_{\mathbf{3}}$ & $\boldsymbol{P}_{\mathbf{4}}$ & $\boldsymbol{P}_{\mathbf{5}}$ & $\boldsymbol{P}_{\mathbf{6}}$ & $\boldsymbol{P}_{\mathbf{7}}$ & $\boldsymbol{P}_{\mathbf{8}}$ & $\begin{array}{c}\text { arithmetic } \\
\text { average }\end{array}$ & $\begin{array}{c}\text { Geometric } \\
\text { average }\end{array}$ \\
\hline $\boldsymbol{w}_{1}$ & 0.41 & 0.35 & 0.25 & 0.27 & 0.22 & 0.42 & 0.36 & 0.42 & 0.34 & 0.33 \\
\hline $\boldsymbol{w}_{2}$ & 0.09 & 0.13 & 0.12 & 0.11 & 0.14 & 0.11 & 0.10 & 0.18 & 0.12 & 0.12 \\
\hline $\boldsymbol{w}_{3}$ & 0.29 & 0.25 & 0.35 & 0.36 & 0.40 & 0.25 & 0.31 & 0.22 & 0.90 & 0.30 \\
\hline $\boldsymbol{w}_{4}$ & 0.06 & 0.07 & 0.13 & 0.11 & 0.12 & 0.11 & 0.12 & 0.13 & 0.11 & 0.10 \\
\hline $\boldsymbol{w}_{5}$ & 0.15 & 0.22 & 0.17 & 0.14 & 0.11 & 0.11 & 0.11 & 0.06 & 0.13 & 0.13 \\
\hline $\mathrm{Cl}$ & 0.03 & 0.06 & 0.50 & 0.10 & 0.06 & 0.03 & 0.08 & 0.04 & 0.06 & 0.06 \\
\hline $\mathrm{CR}$ & 0.03 & 0.05 & 0.05 & 0.09 & 0.05 & 0.02 & 0.07 & 0.03 & 0.05 & 0.05 \\
\hline
\end{tabular}

Table 2. Average consistency test.

\begin{tabular}{c|c|c|c|c|c|c|c|c}
\hline & $\mathbf{3}$ & $\mathbf{4}$ & $\mathbf{5}$ & $\mathbf{6}$ & $\mathbf{7}$ & $\mathbf{8}$ & $\mathbf{9}$ & $\mathbf{1 0}$ \\
\hline $\mathrm{Rl}$ & 0.52 & 0.88 & 1.11 & 1.26 & 1.35 & 1.42 & 1.13 & 1.51 \\
\hline
\end{tabular}


this calculation, we can see that in course selection, the course form is limited and needs to be considered, so as to avoid the conflict of students' professional courses. If the course form, campus and time are allowed, the course selection is based on random number to ensure the fairness of course selection.

\section{Case analysis of evaluation}

In the evaluation of public health physical education in Colleges and universities, the traditional hundred mark system is adopted to divide the students' comprehensive evaluation results into different grades: 90 points are excellent, 80 points are excellent, 70 points are medium, 60 points are above average, and less than 60 points are unqualified. Through the statistical method, the results of students' mutual evaluation are counted, and the average value is taken as the result of mutual evaluation.

Summative evaluation includes self-evaluation and mutual evaluation of teachers and students. According to the scores of teachers and students' self-evaluation and mutual evaluation, we use the principle of bottom-up to comprehensively evaluate each index. Formative evaluation includes three levels of evaluation, two levels of evaluation and evaluation. The third level evaluation is calculated according to the above results to get the final result. For example, in teacher evaluation, according to the weight of physical and mental status and sub indicators, the evaluation result is $S_{c i}=[88.1779 .8284 .87]$. This data shows that the score of students' cooperation and communication is 88.17 , the score of emotion regulation index is 79.82, and the score of physical quality is 84.87 . The score is 86.03 , the score of skill index is 83.10 , the score of sports participation is 84.32 , and the score of basic knowledge index is 80.77 . Using the same method to carry out the self-assessment of students, the comprehensive score of class indicators is 90.51, and the comprehensive score of extracurricular activities is 87.18 . In terms of students' mutual evaluation, the score of attitude and emotion index was 79.56, and the score of knowledge and skill index was 71.92.
After that, the teacher's evaluation score is 84.70 , the student's self-evaluation is 89.68 , and the student's mutual evaluation is 75.74. According to the evaluation results, the final evaluation result is 84.71 . This result has been evaluated by teachers, students themselves and each other, and the final result is good. From this process, we can see that in the application of AHP, qualitative analysis and quantitative analysis are combined together to realize the objectivity and scientificity of evaluation.

\section{CONCLUSIONS}

The development of public health sports in Colleges and Universities has a great impact on the quality of the whole nation. In this paper, the analytic hierarchy process (AHP) is introduced to the development of public health sports, focusing on the optimization design of public health sports course selection and evaluation system. In the influence index of course selection, the nature, campus, curriculum schedule and course selection time are considered. At the same time, the calculation model of students' course selection priority is constructed by using random number, and the weight is calculated by AHP. In the aspect of students' self-evaluation, the fuzzy mathematics theory is introduced, and the analytic hierarchy process is used to evaluate. According to the experts' opinions, the evaluation system is constructed, covering the evaluation mode, the main body and each sub index, and the weight is determined to construct the evaluation model. Through case analysis, it is proved that the course selection model designed in this paper can alleviate the problem of insufficient resources, and also provides a new idea for course selection and student evaluation. Moreover, the public physical education curriculum belongs to a multi-faceted problem, involving a lot of theories and contents. It is simple to rely on the analytic hierarchy process, and it needs to be optimized.

The author declare no potential conflict of interest related to this article

AUTHORS' CONTRIBUTIONS: The author has completed the writing of the article or critical comments on its knowledge content. This paper can be used as the final manuscript. Every author has made an important contribution to this manuscript. Yu Zhang: write and execute. Xiong Jiang: data processing.

\section{REFERENCES}

1. Barneva RP, Hite PD. Information Technology in Sport Management Curricula. Journal of Educational Technology Systems. 2017; 45(3):326-342.

2. Diedrich KC, Diedrich N. Developing Physical Education Student Leaders through a Leadership Course and a University Collaboration. Strategies A Journal for Physical \& Sport Educators. 2017; 30(1):3-7.

3. Mehta P, McAuley DF, Brown M, Sanchez E, Tattersall RS, Manson JJ, et al. COVID-19: consider cytokine storm syndromes and immunosuppression. Lancet. 2020; 395(10229):1033-4.
4. Schmitt V, Rink L, Uciechowski P. The Th17/Treg balance is disturbed during aging. Exp Gerontol. 2013; 48(12):1379-86.

5. Dorado R, Gomez-Moreno A, Torres-Jimenez E, López-Alba E. An AHP application to select software for engineering education. Computer Applications in Engineering Education. 2014; 22(2):200-208.

6. Gueler MG, Keskin ME, Doeyen A, Hasan Akyer. On teaching assistant-task assignment problem: A case study. Computers \& Industrial Engineering. 2015; 79(1):18-26. 